\title{
ZAGADNIENIA FUNKCJONALNOŚCI PRAWA ROLNEGO: MIĘDZY EUROPEIZACJĄ A LOKALNOŚCIĄ
}

Zagadnienia funkcjonalności prawa, zarówno w odniesieniu do całego systemu, jak i jego poszczególnych gałęzi czy dziedzin, należą do istotnych i wymagają badań. Formułowane zaś w tym zakresie oceny i wnioski moga przyczynić się do tworzenia „dobrego” prawa, zwiększenia jego skuteczności w osiaganiu zakładanych celów czy zmniejszenia kosztów. To stwierdzenie należy odnieść zwłaszcza do prawa rolnego nie tylko ze względu na swoistość rolnictwa jako działu wytwarzania i jego miejsce w gospodarce narodowej, lecz także zasadnicze zmiany legislacji rolnej na przestrzeni ostatnich dwudziestu pięciu lat związane z różnymi etapami rozwoju prawa i gospodarki, a w okresie ostatnich dziesięciu lat $-\mathrm{z}$ objęciem polskiego rolnictwa mechanizmami wspólnej polityki rolnej.

W takim ujęciu wyznaczona tytułem tematyka badawcza nie była przedmiotem całościowego, choćby ogólnego, opracowania, aczkolwiek na wiele kwestii (zwłaszcza na różne przejawy dysfunkcjonalności niektórych regulacji prawnych) została już zwrócona uwaga ${ }^{1}$. Ten aspekt prawa rolnego stał się przedmiotem odrębnych rozważań, ale tylko w odniesieniu do okresu transformacji gospodarki ${ }^{2}$. Ustalenia tam zawarte odnoszą się jedynie do pewnego etapu rozwoju prawa rolnego w warunkach nowego ustroju politycznego i społeczno-gospodarczego. Oczywiście należy do nich sięgnąć, mogą one stanowić doskonały punkt wyjścia oceny minionego ćwierćwiecza, ale problem funkcjonalności prawa rolnego jest znacznie szerszy. Z pewnością nie można go dzisiaj sprowadzić jedynie do odpowiedzi na pytanie, czy normy lub insty-

\footnotetext{
${ }^{1}$ Można tu wymienić, dla przykładu: A. Lichorowicz, Stowarzyszenie Polski z EWG a polskie ustawodawstwo rolne, „Państwo i Prawo” 1992, z. 9, s. 50 i n.; A. Jurcewicz, Prawo rolne w przededniu wejścia Polski do Unii Europejskiej, „Studia Iuridica Agraria” 1, 2000, s. 99 i n.; S. Prutis, Instrumenty prawne polityki strukturalnej $w$ rolnictwie (dysfunkcje $i$ bariery), „Studia Iuridica Agraria” 3, 2003, s. 193 i n.; P. Czechowski, Proces dostosowywania polskiego prawa rolnego $i \dot{z} y w-$ nościowego do prawa Unii Europejskiej, Warszawa 2001; B. Jankowski, Plan Rozwoju Obszarów Wiejskich 2004-2006 - ocena efektywności realizacji polityki strukturalnej, „Studia Iuridica Agraria" 7,2009 , s. 204 i n.

${ }^{2}$ Zob. R. Budzinowski, Zagadnienia funkcjonalności prawa rolnego $w$ okresie transformacji gospodarki, „Ruch Prawniczy, Ekonomiczny i Socjologiczny” 1995, z. 1, s. 7 i n.
} 
tucje tej gałęzi prawa rzeczywiście służyły przebudowie, czy - z tego punktu widzenia - były one wystarczająco funkcjonalne.

Celem niniejszych rozważań jest sformułowanie ogólnej oceny funkcjonalności prawa rolnego w okresie minionego ćwierćwiecza. Osiagnięcie tak określonego celu wymaga konkretyzacji odniesień relatywizujacych ocenę funkcjonalności, dokonania wyboru zagadnień oraz prowadzenia rozważań w sposób bardziej modelowy. Usprawiedliwia ona także rezygnację ze szczegółowej egzemplifikacji działalności legislacyjnej na rzecz omówienia kierunków rozwoju ustawodawstwa oraz wybranych regulacji prawnych, interesujacych z punktu widzenia przedmiotu rozważań.

\section{II}

Zagadnienia funkcjonalności prawa rolnego nie można ograniczyć tylko do kwestii, czy faktyczne skutki obowiązywania jakichś aktów prawnych odpowiadają zadaniom, jakie tym aktom (tj. normom czy instytucjom tam zawartym) wyznaczył swego czasu ustawodawca ${ }^{3}$. Taki punkt odniesienia, jak już wcześniej stwierdzono ${ }^{4}$, nie jest w pełni użyteczny do sformułowania oceny. Należy bowiem mieć na uwadze daleko idace - na przestrzeni czasu - zmiany zarówno samego rolnictwa i gospodarki żywnościowej, polityki, jak i ustawodawstwa dotyczącego tej sfery gospodarowania. Nawet jeśli dany akt prawny został wydany na początku okresu transformacji i nadal obowiązuje, to jego współczesna rola oraz rzeczywiste skutki (o czym dalej) mogą znacznie odbiegać od tych, które można było mu przypisać w chwili wydania.

Jednocześnie zdawać sobie należy sprawę z tego, że dokonanie oceny funkcjonalności prawa rolnego nie jest łatwe nie tylko ze względu na wspomniane zmiany rolnictwa i gospodarki żywnościowej, polityki oraz regulacji prawnych. Trudno jest też ustalić skutki przestrzegania czy stosowania określonych norm prawnych, zwłaszcza że wiele z nich - na etapie stanowienia prawa - można jedynie prognozować, a widoczne są one dopiero po upływie dłuższego czasu. Ich wystapienie, a także kształt, determinuje wiele czynników; są one związane nie tylko z samym rolnictwem, lecz także z jego społeczno-gospodarczym i politycznym otoczeniem. Rolnictwo bowiem jest bardzo złożonym, o licznych uwarunkowaniach, przedmiotem oddziaływania prawnego.

Dlatego w tym miejscu, by skonkretyzować odniesienia relatywizujące ocenę funkcjonalności prawa rolnego, należy sformułować kilka uwag jako założenia wyjśsiowe.

Otóż, po pierwsze, oceniając funkcjonalność prawa rolnego na przestrzeni ostatnich dwudziestu pięciu lat należy mieć na uwadze zmiany samego rolnictwa i jego społeczno-gospodarczego otoczenia, a także miejsca, jakie w ramach całej gospodarki zajmuje ta sfera produkcji materialnej. Bez watpienia inny był poziom rozwoju rolnictwa na początku lat dziewięćdziesiątych, a inny

${ }^{3}$ Co do rozróżnienia ról społecznych i społecznych funkcji prawa zob. Z. Ziembiński, Problemy podstawowe prawoznawstwa, Warszawa 1980, s. 481.

${ }^{4}$ R. Budzinowski, Zagadnienia funkcjonalności..., s. 8. 
jest współcześnie. Wzrosło znaczenie, poza samą ziemia, innych czynników produkcji rolnej, zmieniła się struktura własnościowa i produkcyjna gospodarstw rolnych, uległy zmianie stopień ich powiązania z rynkiem, dostępność kapitału itd. Nadal wszakże polska wieś wymaga modernizacji, zwiększenia wyposażenia w infrastrukturę techniczna, polepszenia efektywności produkcji czy organizacji rynku rolnego.

Po drugie, oceny funkcjonalności prawa rolnego nie można odrywać od celów, jakie polityka społeczno-gospodarcza, a zwłaszcza polityka rolna, wyznacza temu działowi gospodarki. W szczególności należy uwzględnić fakt, że od czasu akcesji Polski do Unii Europejskiej nasze rolnictwo zostało objęte mechanizmami wspólnej polityki rolnej. Właśnie ta polityka przypisuje rolnictwu różne funkcje do spełnienia (obok tradycyjnej wyżywieniowej, np. funkcję społeczna, dochodowa, środowiskowa, kulturowa, klimatyczną itd.) i stara się uwzględnić tzw. nowe wyzwania. Zakłada ona wsparcie rolnictwa i rozwoju obszarów wiejskich w warunkach zapewnienia bezpieczeństwa żywnościowego i bezpieczeństwa żywności przy poszanowaniu wymogów środowiskowych. Zatem punktem odniesienia oceny muszą być również odpowiednie dokumenty programowe i akty prawa unijnego wyrażajace tę politykę oraz programy krajowe.

Po trzecie, ocena funkcjonalności musi być powiązana $\mathrm{z}$ etapami rozwoju prawa rolnego. Minione ćwierćwiecze nie było - właśnie z punktu widzenia rozwoju - jednorodne, charakteryzowało się bowiem pewnymi zasadniczymi zwrotami. Inaczej należy więc spojrzeć na okres transformacji ustrojowej bezpośrednio po 1989 r., inaczej na okres dostosowywania naszego prawa (i rolnictwa) do standardów europejskich w celu uzyskania członkostwa w Unii Europejskiej, a jeszcze inaczej już na lata członkostwa, a więc objęcia naszego rolnictwa mechanizmami wspólnej polityki rolnej. Każdy z wymienionych okresów wymaga innego punktu odniesienia szczegółowej oceny funkcjonalności prawa rolnego, którego przedmiot - z upływem lat - uległ znacznemu rozszerzeniu (ekspansji) ${ }^{5}$.

Po czwarte, oceniając skuteczność jako jeden z aspektów funkcjonalności, trzeba uwzględnić skutki regulacji prawa rolnego. Ocenę można odnosić do efektów stosowania poszczególnych aktów prawnych, ich grup wyodrębnionych według wspólnego przedmiotu normowania (np. w zakresie organizacji i funkcjonowania gospodarstw rolnych, rynku rolnego, rozwoju obszarów wiejskich, bezpieczeństwa żywności, ochrony środowiska w rolnictwie itd.) albo w ujęciu całościowym - do odpowiedzi na pytanie, w jakim stopniu realizują one podstawowe cele wyznaczone przez politykę rolną. Tu mieści się także pytanie formułowane przez ekonomistów ${ }^{6}$, w jakiej mierze środki unijne przeznaczone na wsparcie rolnictwa i obszarów wiejskich przyczyniły się do osiagnięcia zakładanych celów i co zrobić, by zwiększyć efektywność ich wydatkowania.

\footnotetext{
${ }^{5}$ Szerzej o ekspansji prawa rolnego zob. R. Budzinowski, Problemy ogólne prawa rolnego. Przemiany podstaw legislacyjnych i koncepcji doktrynalnych, Poznań 2008, s. 127 i n.

${ }^{6}$ Zob. W. Czubak, Rozwój rolnictwa w Polsce z wykorzystaniem wybranych mechanizmów wspólnej polityki rolnej Unii Europejskiej, Poznań 2013, s. 6.
} 
Jak widać, ocena funkcjonalności prawa rolnego wymaga wielu punktów odniesienia, są one nadto złożone i zmienne w czasie. Dokonanie jej w sposób szczegółowy wymagałoby opracowania monograficznego. W niniejszych rozważaniach akcent będzie spoczywał na kwestiach bardziej ogólnych, uwzględniających zasadnicze tendencje rozwoju prawa rolnego, w tym zwłaszcza fakt, że prawo to obejmuje unijne prawo rolne i prawo rolne krajowe ${ }^{7}$. To pierwsze daje wyraz procesom integracji europejskiej, zwanej po prostu europeizacją. Natomiast prawo rolne krajowe, zwłaszcza w zakresie nieobjętym wspólną polityka rolna, uwzględnia warunki lokalne ${ }^{8}$. Ta uwaga tłumaczy sformułowanie tytułu niniejszego artykułu „między europeizacją a lokalnością”.

\section{III}

Rozważania o funkcjonalności prawa rolnego wypada rozpocząć od okresu transformacji ustroju i gospodarki nie tylko dlatego, że otworzył on drogę do dalszych przemian, lecz także dlatego, że sformułowane wówczas kierunki rozwoju znalazły wyraz $\mathrm{w}$ dokumentach programowych ${ }^{9}$ oraz $\mathrm{w}$ regulacjach prawnych. Zmiany w rolnictwie zostały powiązane ze zmianami całej gospodarki, aczkolwiek reformy w tym dziale nieco wyprzedziły zasadnicze reformy rynkowe i systemowe. Ceny rolne zostały „uwolnione” jeszcze w 1989 r. przez tzw. rząd przedsolidarnościowy, co wszakże - ze względu na monopolizację skupu produktów rolnych oraz słabość gospodarki - nie przyniosło spodziewanych pozytywnych efektów ${ }^{10}$.

Ujawniły się bariery rozwoju rolnictwa, wynikające zarówno z jego naturalnej słabości, jak i z uwarunkowań makroekonomicznych (np. ograniczony popyt na żywność na skutek zubożenia społeczeństwa, a także zwiększonego importu, wzrost bezrobocia na wsi, obniżenie opłacalności produkcji rolnej, spadek dochodów rolniczych itd. $)^{11}$. Okazało się, że bez aktywnej polityki państwa wspomniany sektor nie mógłby się rozwijać, a Polska stałaby się importerem żywności, nie wykorzystując własnych możliwości wytwórczych. Harmonijny przebieg procesu transformacji wymagał uruchomienia interwencji

\footnotetext{
${ }^{7}$ Wymienia się jeszcze międzynarodowe prawo rolnictwa.

${ }^{8}$ R. Budzinowski, Prawo rolne między globalizacja, europeizacja i lokalnościa, w: E. Kremer, Z. Truszkiewicz (red.), Rozprawy i studia. Ksiega pamiatkowa dedykowana Profesorowi Aleksandrowi Lichorowiczowi, Kraków 2009, s. 57 i n.

${ }^{9}$ Zob. np. opracowane przez Rząd w listopadzie 1990 r. Założenia polityki rolnej oraz przyjęte przez Sejm RP uchwałą z 15 września 1994 r. (MP Nr 53, poz. 445) Zatożenia polityki spoteczno-gospodarczej dla wsi, rolnictwa i gospodarki żywnościowej.

${ }^{10}$ Zob. np. ocenę A. Stelmachowskiego, w: P. Czechowski et al., Polskie prawo rolne na tle ustawodawstwa Unii Europejskiej, Warszawa 1994, s. 217; J. Okuniewski, Procesy przystosowawcze $w$ rolnictwie $i$ na wsi w latach 1990-1992 (od systemu dyrektywnego do rynkowego $w$ Polsce), „Wieś i Rolnictwo” 1993, nr 2, s. 7 i n.

${ }_{11}$ Zob. dane zawarte w Raporcie o stanie rolnictwa $i$ gospodarki żywnościowej opracowanym przez Ministerstwo Rolnictwa i Gospodarki Żywnościowej, Warszawa, 20 czerwca 1994; J. Lewandowski, Rolnictwo w procesie przemian systemowych, „Wieś i Rolnictwo” 1992, nr 2, s. 41 i n.
} 
publicznej w rolnictwie, taką potrzebę uzasadniały również doświadczenia państw o ugruntowanej gospodarce rynkowej ${ }^{12}$. Dlatego po kilku latach przemian program polityki wobec wsi, rolnictwa i gospodarki żywnościowej został wzbogacony o wiele nowych instrumentów, zapowiadał on również opracowanie licznych aktów prawnych ${ }^{13}$.

W płaszczyźnie normatywnej pierwsze lata transformacji gospodarki przyniosły daleko idace modyfikacje prawa rolnego zmierzajace w jednym kierun$\mathrm{ku}$ - znacznego ograniczenia specjalnej regulacji prawnorolnej. W wyniku zmiany Konstytucji ustawą z 29 grudnia 1989 r. zostały zniesione m.in. szczególne postanowienia dotyczace rolnictwa; do tego sektora odnosiły się jedynie ogólne konstrukcje zasady swobody działalności gospodarczej oraz gwarancji własności ${ }^{14}$. W ustawodawstwie zwykłym natomiast zmiany polegały przede wszystkim na uchyleniu bądź modyfikacji tych instrumentów prawnych, które nie odpowiadały gospodarce rynkowej ${ }^{15}$. Spowodowały one przekształcenia społecznych ról prawa rolnego; zmniejszyło się istotnie znaczenie roli organizacyjnej i stymulacyjnej, zmieniła się też treść roli ochronnej ${ }^{16}$. Dlatego podzielić należy sformułowaną wówczas opinię W. Pańki o kryzysie prawa rolnego w płaszczyźnie legislacyjnej ${ }^{17}$, jak też odnotować postulaty wzbogacenia instrumentacji prawnej adekwatnej do nowej rzeczywistości ${ }^{18}$.

Natomiast regulacje prawne powołujace do życia nowe, nieznane uprzednio instytucje były nieliczne, wprowadzane stopniowo i jakby z pewnym opóźnieniem. Warto w tym miejscu wspomnieć zwłaszcza o utworzeniu już w czerwcu 1990 r. Agencji Rynku Rolnego, o nowej ustawie o ubezpieczeniu społecznym rolników z grudnia tego samego roku oraz o restrukturyzacji i prywatyzacji państwowej własności w rolnictwie ustawą z października $1991 \mathrm{r}^{19}$ Ta pierwsza agencja „rolna” $\mathrm{z}$ wielu względów nie mogła sprostać wyznaczonym jej zadaniom ${ }^{20}$, natomiast dwie ostatnie ustawy, obowiązujące do dziś, zostały poddane bardzo licznym nowelizacjom. Pewne ożywienie działalności

12 Por. B. Gregor, Procesy dostosowawcze indywidualnych gospodarstw rolnych do zmian w otoczeniu rynkowym, „Wieś i Rolnictwo” 1993, nr 3, s. 55; A. Czyżewski, Makroekonomiczne zależności $w$ procesie transformacji rolnictwa, „Wieś i Rolnictwo” 1994, nr 3-4, s. 95.

${ }_{13}$ Zob. wspomniane już Założenia polityki społeczno-gospodarczej dla wsi, rolnictwa $i$ gospodarki żywnościowej.

14 Zob. art. 6 i 7 Konstytucji w brzmieniu nadanym ustawą z 29 grudnia 1989 r., Dz. U. Nr 75, poz. 444 .

${ }_{15}$ Warto w tym miejscu wspomnieć zwłaszcza o zniesieniu szczególnej regulacji w zakresie przeniesienia własności nieruchomości rolnych i zmianie przepisów o dziedziczeniu gospodarstw rolnych ustawą z 28 lipca 1990 r. o zmianie ustawy - Kodeks cywilny, Dz. U. Nr 55, poz. 321.

${ }_{16}$ Tak W. Pawlak, Role społeczne prawa rolnego w warunkach przebudowy systemu gospodarczego w Polsce, w: Z zagadnień prawa cywilnego. Ksiega dedykowana Profesorowi A. Stelmachowskiemu, Białystok 1991, s. 135 i n.

17 W. Pańko, Prawo rolne. Kryzys czy wielki zwrot?, w: Z zagadnień prawa..., s. 481.

${ }_{18}$ Zob. S. Prutis, Adekwatność instrumentów prawnych do potrzeb rozwoju polskiego rolnictwa, w: Z zagadnień prawa..., s. 159 i n.

${ }_{19}$ Ustawa z 7 czerwca 1990 r. o Agencji Rynku Rolnego, Dz. U. Nr 39, poz. 223; ustawa z 20 grudnia 1990 r. o ubezpieczeniu społecznym rolników, Dz. U. 1991, Nr 7, poz. 24; ustawa z 19 września 1991 r. o gospodarowaniu nieruchomościami rolnymi Skarbu Państwa oraz o zmianie niektórych ustaw, Dz. U. Nr 107, poz. 464.

${ }^{20}$ Tak A. Stelmachowski, w: P. Czechowski et al., op. cit., s. 218. 
ustawodawczej w sferze rolnictwa nastapiło w kolejnych latach, dotyczyło wielu aspektów tej dziedziny gospodarki, zwłaszcza w zakresie funkcjonowania rynku rolnego, w mniejszym stopniu w odniesieniu do struktur rolnych czy infrastruktury wsi i rolnictwa ${ }^{21}$.

\section{IV}

Jeszcze $\mathrm{w}$ pierwszej połowie lat dziewięćdziesiątych pojawił się także inny punkt odniesienia oceny polskiego prawa rolnego - prawo Unii Europejskiej ${ }^{22}$. Formułowane wówczas na podstawie ich porównania spostrzeżenia wskazywały na pewną dysharmonię między prawem polskim a unijnym ${ }^{23}$. Zagadnienie dostosowania naszego prawa do standardów europejskich stało się przedmiotem szczególnej uwagi zwłaszcza po wejściu w życie Układu o stowarzyszeniu Polski ze Wspólnotami Europejskimi i ich państwami członkowskimi. Działania dostosowawcze, określone w stosownych dokumentach programowych, objęły nie tylko legislację, lecz także administrację publiczna w rolnictwie ${ }^{24}$. W stanowisku negocjacyjnym Polski w obszarze „Rolnictwo”, przekazanym stronie unijnej w grudniu 1999 r., Rada Ministrów zobowiązała się do wprowadzenia do 31 grudnia 2002 r. do porządku prawnego całości rozwiązań prawnych i instytucjonalnych, które miały umożliwić stosowanie w Polsce instrumentów wspólnej polityki rolnej.

W rezultacie od połowy 2000 r. rozpoczał się okres bardzo intensywnej działalności legislacyjnej. Do dnia podpisania traktatu akcesyjnego (tj. do 16 kwietnia 2003 r.) Sejm uchwalił bardzo obszerną listę ustaw, które często regulowały zagadnienia zupełnie nowe w naszym ustawodawstwie. Można tu wymienić, dla przykładu, ustawy dotyczące organizacji niektórych rynków rolnych (np. mleka, cukru, owoców i warzyw itd.), ustawę z 15 września 2000 r. o grupach producentów rolnych i ich związkach oraz o zmianie innych ustaw ${ }^{25}$, ustawę z 16 kwietnia 2001 r. o rentach strukturalnych w rolnictwie ${ }^{26}$, ustawę z 16 marca 2001 r. o rolnictwie ekologicznym ${ }^{27}$, czy ustawę z 25 lipca 2001 r.

${ }^{21}$ Bliższe omówienie oraz ocena R. Budzinowski, Zagadnienia funkcjonalności..., zwłaszcza s. $11 \mathrm{i} \mathrm{n.}$

${ }^{22} \mathrm{Na}$ co wskazuje choćby tytuł powoływanego już podręcznika: P. Czechowski et al., op. cit.

${ }_{23}$ Zob. np. M. Błażejczyk, Polityczno-legislacyjny dysonans $w$ dażeniu do zintegrowania polskiego rolnictwa z Europejska Wspólnota Gospodarcza, „Prawo Rolne” 1991, z. 1, s. 5 i n.; A. Lichorowicz, Stowarzyszenie Polski z EWG a polskie ustawodawstwo rolne, „Państwo i Prawo”1992, z. 9, s. 50; idem, Stan polskiego prawa rolnego na tle ustawodawstwa rolnego Wspólnoty Europejskiej, „Przegląd Legislacyjny” 1995, nr 5, s. 12 i n.

${ }^{24}$ Bliżej R. Budzinowski, Z problematyki dostosowania prawa rolnego $i$ administracji publicznej $w$ rolnictwie do realizacji Wspólnej Polityki Rolnej, w: „Prawo i Administracja”, t. 4 (red. R. Budzinowski), 2005, s. 9 i n.

${ }_{25}$ Dz. U. Nr 88, poz. 983 ze zm.

26 Dz. U. Nr 52, poz. 539 ze zm.

27 Dz. U. Nr 38, poz. 452. 
o krajowym systemie ewidencji gospodarstw rolnych i zwierząt gospodarskich oraz o zmianie niektórych ustaw ${ }^{28}$.

Zdarzało się, że polskie regulacje powtarzały treść regulacji unijnych, stanowiły ich odwzorowanie (obrazowo nazywane „kalkowaniem”). Ustawodawca miał również na uwadze możliwości finansowania wsparcia z budżetu państwa, o czym świadczyło wprowadzenie wspomnianej już instytucji rent strukturalnych. Renty te były finansowane ze środków krajowych, a rygorystyczne warunki ich uzyskania oraz niska wysokość uniemożliwiały szersze wykorzystanie tej instytucji w praktyce. Nie cieszyła się ona większym zainteresowaniem rolników ${ }^{29}$.

Wspomnieć w tym miejscu wypada o doświadczeniach związanych z realizacja pomocy przedakcesyjnej, a zwłaszcza z realizacją Specjalnego Programu Przedakcesyjnej Pomocy na rzecz Rolnictwa i Rozwoju Obszarów Wiejskich (w skrócie: SAPARD) ${ }^{30}$. Jednym z jego zadań była poprawa warunków prowadzenia działalności gospodarczej i tworzenie miejsc pracy. Obejmowało ono też działania związane z wielofunkcyjnym rozwojem obszarów wiejskich. Samo wdrażanie wspomnianego Programu trwało bardzo długo. Wprawdzie jego cele nie zostały osiagnięte w okresie przedakcesyjnym, ale działania podejmowane w zakresie wdrażania umożliwiły zdobycie doświadczeń przez Agencję Restrukturyzacji i Modernizacji Rolnictwa, a także uzasadniały potrzebę pewnego uproszczenia czy ułatwienia procedur. Natomiast beneficjenci omawianego programu uzyskali niezbędną wiedzę i doświadczenie ułatwiające im w przyszłości korzystanie ze środków wsparcia.

Szybkiemu rozwojowi ustawodawstwa, uzasadnionemu potrzebą dostosowania naszego prawa do standardów europejskich, nie towarzyszył równie intensywny rozwój prawa rolnego w dziedzinach nieobjętych wspólną polityka rolna. W tym ostatnim zakresie zmiany polegały przede wszystkim na nowelizacji uprzednio wydanych ustaw. Najbardziej charakterystycznym przykładem są kolejne modyfikacje wspomnianej już ustawy o gospodarowaniu nieruchomościami rolnymi Skarbu Państwa, co świadczy nie tylko o dostosowywaniu tej regulacji do nowych warunków, lecz także o braku pewnej koncepcji, wizji przyszłego ustroju rolnego w momencie jej uchwalania. Ta wizja ustroju rolnego znalazła wyraźny normatywny wyraz dopiero w art. 23 Konstytucji RP z 1997 r., który uznał gospodarstwa rodzinne za podstawę ustroju rolnego ${ }^{31}$.

Postanowienia konstytucyjne w zakresie rozwoju prawa rolnego spełniaja, patrząc z dzisiejszej perspektywy, przede wszystkim rolę korygująca, a nie kreująca. Przykładem może być wyrok Trybunału Konstytucyjnego z 31 stycznia 2001 r., który spowodował daleko idące modyfikacje istniejącego

${ }^{28}$ Dz. U. Nr 125, poz. 1363.

${ }^{29}$ Bliżej o rentach strukturalnych zob. J. Zięba, Renty strukturalne w ustawodawstwie rolnym, Warszawa 2013.

${ }^{30}$ O programie SAPARD zob. B. Kozłowska, w: A. Jurcewicz (red.), B. Kozłowska, E. Tomkiewicz, Wspólna polityka rolna, Warszawa 2004, s. 195 i n. oraz W. Czubak, op. cit., s. 139 i n.

${ }^{31}$ Szerzej o znaczeniu wymienionego przepisu Konstytucji zob. zwłaszcza: A. Lichorowicz, Konstytucyjne podstawy ustroju rolnego RP ( $w$ świetle art. 23 Konstytucji), „Studia Iuridica Agraria" 1, 2000, s. 25 i n.; R. Budzinowski, Problemy ogólne..., s. 60 i n. 
dotychczas modelu dziedziczenia gospodarstw rolnych ${ }^{32}$. Natomiast gdy chodzi o nowe regulacje, największe znaczenie ma ustawa z 13 kwietnia 2013 r. o kształtowaniu ustroju rolnego ${ }^{33}$, uchwalona kilka dni przed podpisaniem traktatu akcesyjnego, która też kolejny raz zmieniła m.in. ustawę o scalaniu i wymianie gruntów oraz wspomnianą wyżej ustawę o gospodarowaniu nieruchomościami rolnymi Skarbu Państwa. Wprowadziła ona pewną formę kontroli obrotu nieruchomościami rolnymi. Jednakże, wbrew tytułowi, przedmiot regulacji tej ustawy, jak i przewidziane instrumenty nie pozwalaja przypisać jej roli istotnego narzędzia w kształtowaniu wspomnianego ustroju ${ }^{34}$. Wypada w tym miejscu odnotować, że zmiany w krajowym prawie rolnym w okresie przedakcesyjnym tylko w niewielkiej części spełniały postulaty formułowane w tym czasie przez doktrynę ${ }^{35}$.

\section{V}

Podpisanie 16 kwietnia 2003 r. w Atenach traktatu akcesyjnego otworzyło kolejny etap w rozwoju prawa rolnego, wprowadziło też nowy punkt odniesienia oceny funkcjonalności tego prawa. W ramach członkostwa Polski w Unii Europejskiej wyraźnie wyróżniają się dwa okresy, tj. pierwszy okres obejmujaccy lata od 2004 (od 1 maja tego roku) do 2006 r. oraz drugi - od 2007 do 2013 r.

Członkostwo w UE spowodowało istotne zmiany w dotychczasowym procesie dostosowawczym. Możliwe już było zachowanie reguł i zasad dotyczących wdrażania prawa unijnego do krajowego porządku prawnego. Ustawodawca znowelizował, a nawet uchylił wiele ustaw, które albo powielały regulacje prawne Unii Europejskiej, albo wykazywały odstępstwa od tych regulacji w sferze prawa materialnego. Nowe akty prawne miały wejść w życie z dniem uzyskania przez Polskę członkostwa w Unii Europejskiej, tj. 1 maja 2004 r.

Można tu wymienić, jako przykład, ustawę z 11 marca 2004 r. o Agencji Rynku Rolnego i organizacji niektórych rynków rolnych ${ }^{36}$. Odwołuje się ona do zadań wyznaczonych wspólną polityką rolna, a co do organizacji niektórych rynków (m.in. mięsa, wina, cukru itd.) jej regulacja mieści się w zakresie określonym przepisami Unii Europejskiej. Nowa ustawa z 20 kwietnia 2004 r. o organizacji rynku mleka i przetworów mlecznych ${ }^{37}$ w dużej mierze ma charakter kompetencyjny, tzn. reguluje ona zadania i właś-

32 Bliżej zob. zwłaszcza A. Lichorowicz, Szczególny porządek dziedziczenia gospodarstw rolnych w Polsce po orzeczeniu Trybunału Konstytucyjnego z dnia 31 stycznia 2001 r., „Rejent” 2001, nr 9 .

${ }^{33}$ Dz. U. Nr 64, poz. 592 ze zm.

${ }^{34}$ Zob. bliżej, A. Lichorowicz, Instrumenty oddziatywania na strukture gruntowa Polski w ustawie z dnia 11 kwietnia 2003 r. o ksztattowaniu ustroju rolnego, „Kwartalnik Prawa Prywatnego" 2004, nr 2.

35 Zob. zwłaszcza A. Lichorowicz, Podstawowe kierunki rozwoju..., s. 53 i n.

${ }^{36}$ Dz. U. Nr 42, poz. 386 ze zm.

37 Dz. U. Nr 93, poz. 897. 
ciwość jednostek organizacyjnych oraz organów w zakresie organizacji rynku mleka i przetworów mlecznych określonej przepisami Unii Europejskiej. Ustawa ta uchyliła poprzednią ustawę pod tym samym tytułem z 2001 r., będacca odwzorowaniem regulacji wspólnotowych. Podobnie nowa ustawa z 20 kwietnia 2004 r. o rolnictwie ekologicznym ${ }^{38}$, która sprecyzowała zadania i właściwość organów i jednostek organizacyjnych w zakresie rolnictwa ekologicznego uregulowanego w wymienionych w tej ustawie aktach prawa wspólnotowego.

Traktat akcesyjny, określając stosowanie niektórych instrumentów wspólnej polityki rolnej w Polsce, przesądził także o treści części ustaw. Tytułem przykładu można tu przytoczyć ustawę z 28 listopada 2003 r. o wspieraniu rozwoju obszarów wiejskich ze środków pochodzących z Sekcji Gwarancji Eu-

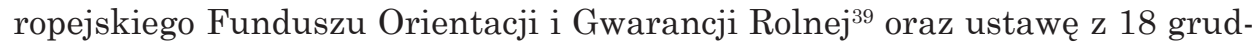
nia 2003 r. o płatnościach bezpośrednich do gruntów rolnych ${ }^{40}$.

Okres 2004-2006 charakteryzuje nie tylko intensywna działalność legislacyjna w obszarach objętych wspólną polityką rolna. Znacznej rozbudowie uległ przedmiot regulacji prawnorolnych, który objął problematykę rolno-żywnościową i rolno-środowiskowa. Agencje „rolne”, tj. Agencja Rynku Rolnego oraz Agencja Restrukturyzacji i Modernizacji Rolnictwa, zostały dostosowane do realizacji mechanizmów wspólnej polityki rolnej, zyskały status agencji płatniczych, zdobyły niezbędne doświadczenia w dysponowaniu środkami wsparcia. Można by, tytułem przykładu, wskazać, że limit środków przeznaczonych na realizację Planu Rozwoju Obszarów Wiejskich został wykorzystany w 98\% ${ }^{41}$. Ogromnym zainteresowaniem, ze względu na podwyższenie wysokości oraz liberalizację przesłanek przekazania gospodarstwa rolnego, cieszyły się - w ramach omawianego Planu - renty strukturalne. Do końca 2006 r. zostało wydanych ponad 50 tys. decyzji w sprawie przyznania tego świadczenia ${ }^{42}$. Również duże zainteresowanie adresatów pomocy towarzyszyło realizacji Sektorowego Programu Operacyjnego „Restrukturyzacja i modernizacja sektora żywnościowego oraz rozwój obszarów wiejskich 2004-2006”43. Na sytuację ekonomiczną gospodarstw rolnych istotnie wpłynęły dopłaty bezpośrednie ${ }^{44}$. Nie można jednak nie odnotować występujących braków w przyznawaniu wsparcia, polegających m.in. na rozproszeniu środków, dążeniu do ich dystrybucji, a nie

${ }^{38}$ Dz. U. Nr 93, poz. 898.

39 Dz. U. Nr 229, poz. 2273 ze zm.

${ }^{40}$ Dz. U. 2004, Nr 6, poz. 40. Bliżej o ustaleniach rolnych w traktacie akcesyjnym zob. E. Tomkiewicz, w: A. Jurcewicz (red.), B. Kozłowska, E. Tomkiewicz, op. cit., s. 190 i n.

${ }^{41}$ Zob. M. Krasucka, Realizacja programów rozwoju obszarów wiejskich w Polsce w latach 2004-2006, w: S. Sokołowska, A. Biesiaga (red.), Wieś i rolnictwo w procesie zmian, Opole 2008, s. 91 i n.

${ }^{42}$ Według danych Programu Rozwoju Obszarów Wiejskich na lata 2007-2013 (Warszawa 2007, s. 139) przekazano około 450 tys. ha użytków rolnych, przy czym w przejęciu tych użytków duży udział mieli następcy w wieku do 40 lat.

${ }^{43}$ Co do oceny realizacji tego programu zob. M. Krasucka, op. cit., s. 95 oraz M. Drygas, T. Kmieciński, Ocena realizacji Sektorowego Programu Operacyjnego „Restrukturyzacja i modernizacja sektora żywnościowego oraz rozwój obszarów wiejskich 2004-2006”. Kontynuacja Programu SAPARD, „Wieś i Rolnictwo” 2007, nr 4, s. 92 i n.

${ }^{44} \mathrm{O}$ roli dopłat bezpośrednich zob. bliżej W. Czubak, op. cit., s. 221 i n. 
wyborze jak najefektywniejszej alokacji (w tym zakresie zbyt mały nacisk na modernizację gospodarstw $)^{45}$.

Kolejny okres finansowania wspólnej polityki rolnej, obejmujący lata 2007-2013, przyniósł istotne zmiany unijnego prawa rolnego, a w ślad za tym - także prawa krajowego. Jeszcze w 2005 r. zostało wydane rozporządzenie Rady (WE) nr 1698/2005 w sprawie wsparcia rozwoju obszarów wiejskich przez Europejski Fundusz Rolny na rzecz Rozwoju Obszarów Wiejskich ${ }^{46}$, dotyczące już nowego okresu. Z innych podstawowych aktów prawnych, o charakterze „europejskich kodeksów rolnictwa”" ${ }^{47}$, warto wymienić zwłaszcza rozporządzenie Rady (WE) nr 1234/2007 z 22 października 2007 r. ustanawiające wspólną organizację rynków rolnych oraz przepisy szczegółowe dotyczące niektórych produktów rolnych ${ }^{48}$, a także rozporządzenie Rady (UE) nr 73/2009 z 29 września 2003 r. ustanawiające szczegółowe zasady w ramach systemów wsparcia bezpośredniego ${ }^{49}$. Wymienione akty były wielokrotnie nowelizowane, towarzyszyła im również intensywna działalność prawodawcza w postaci aktów wykonawczych, wyraźnie zaznaczyła się także aktywność legislacyjna w zakresie zwłaszcza bezpieczeństwa żywności i jej jakości.

Stosunkowo szybko zostały wydane krajowe akty prawne wdrażajacce stosowanie nowych aktów prawa unijnego. Dla przykładu, już 7 marca $2007 \mathrm{r}$. Sejm uchwalił ustawę o wspieraniu rozwoju obszarów wiejskich z udziałem środków Europejskiego Funduszu Rolnego na rzecz Rozwoju Obszarów Wiejskich $^{50}$, natomiast ustawa z 26 stycznia 2007 r. o płatnościach w ramach systemów wsparcia bezpośredniego ${ }^{51}$ określił zadania, właściwość organów i jednostek organizacyjnych $\mathrm{w}$ zakresie dotyczącym tych płatności oraz tryb ich przyznawania rolnikom, przeprowadzania kontroli i ich wypłaty.

W ślad za uchwalaniem nowych czy nowelizowaniem dotychczasowych aktów prawa unijnego następowały również liczne zmiany w prawie krajowym. To zjawisko „inflacji” przepisów nie służyło pewności i jasności prawa, ale umożliwiało wdrażanie prawa unijnego i korzystanie ze środków pomocowych. Niektóre zmiany były sugerowane przez Polskę. Dla przykładu, Polska uzyskała zgodę Komisji Europejskiej na przesunięcie środków finansowych w ramach Programu Rozwoju Obszarów Wiejskich na lata 2007-2013 na realizację programu rent strukturalnych, ale pod warunkiem wykazania większego wpływu tego instrumentu na poprawę struktury obszarowej gospodarstw. Spowodowało to zmianę polskich przepisów w zakresie przesłanek uzyskania renty, a także powiązania tego programu z „Ułatwianiem startu młodym rolnikom" ${ }^{2}$.

${ }_{45}$ Por. B. Jankowski, op. cit., s. 204 i n.

${ }^{46}$ Dz. Urz. UE L 277 z 21 października 2005 r. (ze zm.), s. 1.

${ }^{47}$ Wyrażenie F. Albisinniego, Europejskie prawo rolne po Traktacie z Lizbony pomiędzy interwencja a regulacja. Europejskie kodeksy rolnictwa, „Przegląd Prawa Rolnego” 2011, nr 1, s. 111 i n.

${ }^{48}$ Dz. Urz. UE L 299 z 16 listopada 2007 r. (ze zm.), s. 1.

${ }^{49}$ Dz. Urz. UE L 270 z 21 października 2003 r. (ze zm.), s. 1.

${ }^{50}$ Dz. U. Nr 64, poz. 427 ze zm.

${ }^{51}$ T.jedn.: Dz. U. 2012, poz. 1164 ze zm.

${ }^{52}$ Zob. R. Budzinowski. A. Suchoń, K. Błażejewska, Rozwój prawa rolnego w ostatnich latach, „Przegląd Prawa Rolnego” 2012, nr 2, s. 35 i n. 
Ożywionej aktywności ustawodawcy krajowego w zakresie wdrażania prawa unijnego nie towarzyszyła, niestety, równie intensywna działalność legislacyjna w obszarach nieobjętych wspólną polityką rolną. Ciężar tej działalności spoczywał przede wszystkim na zmianie dotychczas wydanych aktów prawnych, bardzo często już wielokrotnie nowelizowanych. Można tu wymienić, tytułem przykładu, powoływane już ustawy: o gospodarowaniu nieruchomościami rolnymi Skarbu Państwa z 1991 r., o ubezpieczeniu społecznym rolników z 1990 r., czy o kształtowaniu ustroju rolnego z 2003 r., a także o ochronie gruntów rolnych i leśnych z 1995 r. i o scalaniu i wymianie gruntów z 1982 r.

Odnotować jednak należy, że toczyły się lub nadal są prowadzone prace nad reformą opodatkowania rolnictwa, nad projektem ustawy o spółdzielniach rolników, uregulowaniem kwestii sprzedaży bezpośredniej produktów rolnych, czy odnawialnych źródeł energii. Zakłada się szersze wykorzystanie biogazu rolniczego, a w programie „Innowacyjna gospodarka - rolnictwo energetyczne" przewiduje się wybudowanie do 2020 r. co najmniej jednej biogazowni w każdej gminie ${ }^{53}$. Nie można tu pomijać aktywnego udziału Polski w dyskusji o przyszłości wspólnej polityki rolnej. Po raz pierwszy nasz kraj w tak szerokim zakresie wypowiadał się na temat przyszłego kształtu tej polityki, w tym także o projektach legislacyjnych wyznaczajacych jej ramy prawne na lata $2014-2020^{54}$.

\section{VI}

Punktem wyjścia oceny funkcjonalności jest ogólne stwierdzenie, że okres minionego dwudziestopięciolecia charakteryzowały daleko idące zmiany prawa rolnego, aczkolwiek przebiegające w dwóch kierunkach - od jego ograniczenia do rozbudowy.

Wprowadzenie gospodarki rynkowej przyniosło znaczne ograniczenie specjalnej regulacji prawnorolnej, gdyż ciężar działalności ustawodawczej - jak już wcześniej wspomniano - spoczywał na nowelizacji bądź na uchylaniu aktów prawnych, które były nieadekwatne do nowego ustroju. Aktywność legislacyjną polegającą na wydawaniu nowych regulacji dotyczacych rolnictwa, wsi i gospodarki żywnościowej niewątpliwie ograniczało liberalne podejście do gospodarki, brak polityki rolnej oraz wizji przyszłego ustroju rolnego. Świadcza o tym kolejne zmiany uchwalonej w pierwszych latach transformacji i powoływanej już ustawy o gospodarowaniu nieruchomościami rolnymi Skarbu Państwa. Dlatego, jak stwierdzono w literaturze ${ }^{55}$, prawo rolne właśnie w kontekście transformacji nie było jeszcze wystarczająco funkcjonalne, a zwiększenie

${ }^{53}$ Zob. K. Błażejewska, Prawne aspekty produkcji $i$ wykorzystywania biogazu rolniczego $w$ Polsce, „Przegląd Prawa Rolnego” 2010, nr 1, s. 97 i n.

${ }^{54}$ Zob. bliżej R. Budzinowski, O przyszłości wspólnej polityki rolnej - uwagi z perspektywy Polski, w: Z zagadnień prawa rolnego, cywilnego i samorzqdu terytorialnego. Księa Jubileuszowa Profesora Stanistawa Prutisa, Białystok 2012, s. 51 i n. (i powołaną tam literaturę).

${ }^{55}$ R. Budzinowski, Zagadnienia funkcjonalności..., s. 17. 
funkcjonalności zostało powiązane z zapowiadanym ożywieniem działalności legislacyjnej.

To ożywienie wystapiło w okresie dostosowywania naszego prawa rolnego do standardów europejskich. W tym czasie nastapiła znaczna rozbudowa regulacji prawnych w wielu dziedzinach rolnictwa. Spełnienie wymogów „dostosowawczych” umożliwiło przyjęcie Polski do Unii Europejskiej i objęcie naszego rolnictwa mechanizmami wspólnej polityki rolnej. Z tego punktu widzenia wypada stwierdzić, że prawo rolne w tym okresie było wystarczająco funkcjonalne. Nie można też w tej ocenie pomijać innych pozytywnych aspektów dokonanych zmian w postaci ukształtowania odpowiedniego statusu podmiotów administrujacych sprawami rolnictwa, zdobycia przez nie pewnego doświadczenia w zakresie realizacji pomocy przedakcesyjnej, świadomości konieczności upraszczania procedur, instruowania beneficjentów tej pomocy itd.

Objęcie rolnictwa mechanizmami wspólnej polityki rolnej w ramach członkostwa Polski w Unii Europejskiej zintensyfikowało rozwój prawa rolnego, jego ekspansję, ekologizację i tzw. ruralizację. Można powiedzieć, że motorem rozwoju tej dziedziny prawa stało się prawo unijne. Jego wdrażanie do polskiego porządku prawnego miało na uwadze przede wszystkim maksymalizację transferu środków z Unii Europejskiej i zagwarantowanie ich pełnej absorpcji. Wprawdzie pierwsze lata członkostwa (tj. 2004-2006) przyniosły wiele zmian regulacji „wdrożeniowych”, ale sformułowane wyżej założenie zostało w gruncie rzeczy zrealizowane.

Uzyskane w tym zakresie doświadczenia były następnie wykorzystane w kolejnym okresie programowania, w latach 2007-2013. Nowe regulacje prawne otworzyły szerszą możliwość wsparcia sektora rolnego oraz przekształceń wsi. Wskutek tego wzrosły dochody w bardzo licznej grupie gospodarstw rolnych, poprawiło się techniczne uzbrojenie ziemi i pracy, duże wsparcie skierowane zostało na rozwój obszarów wiejskich. Jednakże na funkcjonalność prawa rolnego w tym okresie programowania należy patrzeć nie tylko w kontekście absorpcji środków unijnych, lecz także, a może nawet przede wszystkim, ich właściwej alokacji, a tu - efektywności. Ten ostatni aspekt wymaga podkreślenia w świetle oceny, że w niewielkim stopniu wsparcie unijne wpłynęło na poprawę zdolności konkurencyjnych gospodarstw rolnych ${ }^{56}$. Zatem polski ustawodawca, wdrażajac nowe regulacje unijne stanowiące ramy wspólnej polityki rolnej na lata 2014-2020, będzie musiał zwrócić większą uwagę na problem alokacji środków pomocowych.

Sformułowane wcześniej twierdzenie o rozwoju prawa rolnego odnosi się przede wszystkim do tych dziedzin, które objęte są wspólną polityką rolną. $\mathrm{W}$ dziedzinach nieobjętych tą polityka, z natury rzeczy uwzględniających aspekt lokalny, działalność polskiego ustawodawcy jest niezwykle skromna. W naszym porządku prawnym nie występują akty z zakresu prawa rolnego o bardzo szerokim zakresie regulacji, mające istotne znaczenie dla ukierunko-

${ }^{56}$ Zob. np. W. Poczta, Wspólna Polityka Rolna po 2013 roku - uzasadnienie, funkcje, kierunki rozwoju w kontekście interesu polskiego rolnictwa, „Wieś i Rolnictwo” 2010, nr 3, s. 42-43; A. Z. Nowak, A. Niewiadomska, Wpływ funduszy strukturalnych na wzrost konkurencyjności polskiego rolnictwa - wybrane aspekty ekonomiczne, w: Z zagadnień prawa rolnego..., s. 322 i n. 
wania rozwoju rolnictwa, jak we Francji czy Włoszech. Brakuje też regulacji uwzględniających współczesne realia rolnictwa i jego otoczenia, swoistych dla tego działu gospodarki. Świadczy to o słabości polskiego ustawodawcy, nie pozwala też na sformułowanie twierdzenia o pełnej funkcjonalności prawa rolnego.

Tymczasem ożywienie działalności legislacyjnej krajowego ustawodawcy w dziedzinach nieobjętych wspólną polityką rolną jest wręcz pożądane. Wymaga ono jednak sformułowania szczegółowej wizji rozwoju polskiego rolnictwa. $\mathrm{O}$ tym, jak trudno jest wprowadzić nowe regulacje prawne w omawianym tu zakresie, świadczą przedłużające się prace legislacyjne nad wymienionymi wcześniej kwestiami. Potrzebne jest więc wsparcie ustawodawcy ze strony nauki prawa, wykorzystanie dorobku zwłaszcza nauk ekonomicznych, a także wniosków płynących z badań prawnoporównawczych. Z tego względu warto zainwestować w rozwój nauki prawa rolnego.

prof. dr hab. Roman Budzinowski

Uniwersytet im. Adama Mickiewicza w Poznaniu

romanb@amu.edu.pl

FUNCTIONALITY OF AGRICULTURAL LAW:

BETWEEN EUROPEANISATION AND LOCALNESS

Sum mary

The purpose of this paper is formulation of a general thesis regarding the functionality of agricultural law in the past quarter of the century. The author has differentiated and analysed three stages of development of Polish agricultural law: (i) immediately after 1989 when political transformations commenced, (ii) the stage of approximation, or harmonisation of Polish law (including agricultural) in order to qualify for EU membership, and (iii) Poland's EU-membership. The introduction of a market economy caused a significant reduction in special legal acts regulating agricultural matters. The increasing functionality of agricultural law at some later date was a result of a revival of legislative activity undertaken with a view of harmonising Polish agricultural laws with the European Union standards. An intensive development of agricultural law was a consequence of including Poland (as a EU-member State) within the CAP mechanism. However, the functionality of agricultural law shall not only be judged from the point of view of the absorption of EU funds, but also, and maybe in particular, from the point of view of their proper allocation and proper management (efficiency). Thus, when new EU regulations constituting the CAP framework for the 2014-2020 period are being implemented in Poland, special care will have to be taken to properly allocate the CAP direct payments. 
Copyright of Journal of Law, Economics and Sociology is the property of Faculty of Law and Administration of Adam Mickiewicz University in Poznan and its content may not be copied or emailed to multiple sites or posted to a listserv without the copyright holder's express written permission. However, users may print, download, or email articles for individual use.

Właścicielem praw autorskich do „Ruchu Prawniczego, Ekonomicznego i Socjologicznego” jest Wydział Prawa i Administracji Uniwersytetu im. Adama Mickiewicza w Poznaniu. Zawartość czasopisma nie może być kopiowana, przesyłana do innych stron internetowych bądź zamieszczana na blogach bez pisemnej zgody wydawcy. Niemniej artykuły można drukować, kopiować lub przesyłać w formie elektronicznej na własny użytek. 